Studia Maritima, vol. XXXI (2018)

ISSN 0137-3587

DOI: $10.18276 / \mathrm{sm} .2018 .31-07$

Gabriela Majewska*

\title{
THE POLISH-LITHUANIAN COMMONWEALTH AND ITS INHABITANTS DURING THE GREAT NORTHERN WAR IN GENERAL MAGNUS STENBOCK'S OPINION
}

Keywords: Poland, Sweden, the Great Northern War, Magnus Stenbock

\begin{abstract}
Summary
Magnus Stenbock was one of the most outstanding commanders in the army of Charles XII during the Great Northern War (1700-1721). Magnus spent the years 1702-1706 in the Polish territory as an invader with the Swedish troops. His attitude towards Poland and the Polish resulted from his war experience, especially the easy victories over the Polish. The victories confirmed the Swedes in their belief about the low military value of the Polish army and favoured a disdainful approach to the inhabitants of the Commonwealth. Although many Poles took sides with the Swedes and collaborated with them, Stenbock did not trust them, he accused them of hypocrisy, duplicity, instability in their opinions, disobedience and unscrupulousness. The situation of the Polish collaborating with Charles XII required a skill of manoeuvring, so that the exacted taxes would be the least possible burdensome, and on the other hand the ruthless methods of exacting the taxes triggered in the Polish resistance and disobedience. Socialising with the Polish aristocracy and gentry Stenbock noticed their quarrels, intrigues, and dissolution. Their lavish life was attractive for the Swedish general who was not accustomed to luxury and splendour. His interest was aroused not only by the exotic way the Polish got dressed, but also by their arms, silverware, carpets, expensive cloths, furs, bedclothes, tablecloths,
\end{abstract}

* dr hab. Gabriela Majewska, prof. UG, Uniwersytet Gdański, Instytut Historii, hisgm@ug.edu.pl. ORCID: 0000-0002-0789-169X. 
mirrors, clocks, paintings. Magnus took many of those artefacts to Sweden as loots. The general harshly judged the Polish battle worthiness, but in defence of Scania against Denmark he formed a levy in mass of peasants following the example of Poland. Staying for five years in Poland Magnus Stenbock had many occasions to get to know the Polish; yet, he quite often gave simplified, exaggerated or unjust opinions. Many traits of the Polish character deserved to be condemned, but their duplicity, disobedience or instability - the features the general complained of - were results of the situation the Poles collaborating with the Swedes found themselves in, and of the way the Swedish army behaved in Poland. Opinions on Poland and its inhabitants given by Magnus Stenbock did not differ from the ones given by Charles XII and other army commanders.

Magnus Gustafsson Stenbock (1664-1717) was one the most outstanding figures among the Swedish decision-making milieu at the beginning of the $18^{\text {th }}$ century and - in addition to Charles XII - his influence on the situation in Poland during the Great Northern War was enormous. He came of one of the oldest and the most influential families related to the Swedish aristocracy (his mother was from De la Gardie family), which played a significant role in his career in the state service. Magnus carried on the military traditions of his family, but was forced to reach the strong social and financial position by himself. His family faced the fate shared by many other old Swedish families under the rule of Charles XI. Gustaw Otto, his father, counsellor of the state, governor of Livonia, governor of Scania, and admiral, at the end of his life was removed from all his influential positions and his wealth was greatly depleted. ${ }^{1}$ Magnus spent his youth in poverty, thanks to which he developed such features as craftiness, ingeniousness, and consequence in pursuing a goal; the features turned out very useful in his career.

Stenbock had excellent military qualifications and valuable experience. When the Great Northern War broke out he had already had behind him a service in the Dutch army, the Swedish army and the imperial army, where he fought against France and was promoted to the rank of colonel. It was typical of the Swedish gentry to begin military service abroad since Charles XI had introduced the rule under which everybody had to start military service from the rank of private. Aristocrats circumvented the rule starting military service abroad and when they

Z. Łakociński, Magnus Stenbock w Polsce. Przyczynek do historii szwedzkich zdobyczy w czasie wojny pótnocnej (Wrocław 1967), 15-16; A. Marklund, "Magnus Stenbock: the Count and the Spy", History Today 60 (2010): 19-20; J. Cavallie, "De höga officerarna. Studier i den svenska militäre hierarkien under 1600 talets senare del", Militärhistoriska studier 4 (1981): 56 ff. 
achieved the rank of colonel they came back to Sweden. ${ }^{2}$ Magnus Stenbock participated in the Great Northern War from the very beginning. When the war broke out he commanded the Dalarna infantry regiment; he and his regiment took part in the battle of Narva (1700), victorious for the Swedes. For his merits he was promoted to the rank of general-major and found himself in the closest circle of the king, he won his confidence and had influence on the young ruler, which aroused envy. Magnus participated in the king's campaigns in the Polish Commonwealth, in the crossing of the (Western) Dvina (Daugava) in July 1701, in the battle of Klissow (Klezow) (July 1702), and in capturing Cracow (August 1702) and Lviv (September 1704); Magnus commanded the siege of Torun (from May to October 1703), was the governor of Warsaw, Cracow and Torun. Charles XII appreciated his loyalty and his military and organisational skills and entrusted him with responsible tasks and missions. In August 1702 the king appointed Stenbock director of the Swedish General War Office in Poland, of which he was head from 1702 to 1706. In 1706 in recognition of his accomplishments he was nominated the general governor of Scania and promoted to the rank of general-lieutenant. In the same year the king appointed him the general Commissioner of the Swedish army in the occupied Saxony. Next he was entrusted with the task to organise a new Swedish army in place of the one lost in the battle of Poltava. In February 1710 Magnus defeated Denmark in the battle of Hälsingborg. Thanks to that victory he was hailed national hero and was conferred the rank of Field Marshal. His streak of success ended with the surrender of the stronghold of Tönningen (May 1713); Magnus was imprisoned by the Danish and in 1717 he died as a prisoner in Copenhagen. ${ }^{3}$

Undoubtedly, the life of Magnus Stenbock was interesting and varied, and his role in the military campaigns of Charles XII - significant. In the Polish historiography, as well as the foreign one, Stenbock is mentioned en passant in the biographies of Charles XII and in the analyses of the Great Northern War. There is a study devoted to Stenbock, especially presenting his participation in the Polish period of the Great Northern War, with emphasis on the plunder of Polish cultural artefacts, entitled Magnus Stenbock w Polsce. Przyczynek do historii szwedzkich zdobyczy w czasie wojny pótnocnej, written by Zygmunt Łakociński, a Polish

2 M. Kopczyński, "Szlachta i państwo w XVI-XVIII wieku - model szwedzki”, Przeglad Historyczny 3 (1996): 645; B. Asker, "Officerarna och det svenska samhället 1650-1700”, Studie Historica Uppsaliensie 133 (1983): 90.

3 Lakociński, Magnus, 16-17. 
Slavist. Among the Swedish biographies of the general it is worth mentioning the works written by Ingvar Eriksson, entitled Karolinen Magnus Stenbock, and by Andreas Marklund entitled Stenbock. Ära och ensamhet i Karl XII:s tid. ${ }^{4}$

The present article is an attempt to show Magnus Stenbock's opinions on the Polish Commonwealth and its inhabitants. Another problem dealt with is an attempt to answer the question whether his opinions and assessments were stereotypical and superficial or resulted from an in-depth knowledge of the country. The author will also indicate the factors that influenced attitudes and behaviours, which the Swedish commander observed in the Polish during the war.

Magnus Stenbock was not only an excellent commander, a brave warrior and skilful organiser within the military sphere. He also was a good speaker and writer, he had a great gift of expressing his thought in a very clear way. When he died he left a rich literary legacy: many official reports, memoranda, instructions, proclamations and private documents (letters and diaries); and just those private documents are the basis for the analysis in the article. From the point of view of the presented subject the reports of his stay in the Polish territory in the years 1702-1703 are the most important: the diary of the expedition of the years 1702 1703, a short description of the expedition of 1704, reports and memoranda addressed to Charles XII, correspondence with Charles XII, letters to his wife, Eva Oxenstierna, a report of the General War Office of the years 1702-1704, dictated by him. ${ }^{5}$ Stenbock's reports are an excellent source thanks to which it is possible to reconstruct emotions and opinions of the author. It should be noted that since the rule of Charles X writing war diaries had been included in the regulations of the Swedish army as obligatory, and it had to be done in battlefield, and not ex post. ${ }^{6}$ Stenbock's reports (diary, description of the expedition, letters to Charles XII) are matter-of-fact, precise, exact, although they also depict dramatic scenes

4 Ibidem; I. Eriksson, Karolinen Magnus Stenbock (Atlantis 2007); A. Marklund, Stenbock. Ära och ensamhet $i$ Karl XII:s tid (Lund: Historiska Media, 2008).

5 Journal över expeditionen 1702-1703af generalmajoren, grefve Magnus Stenbock (henceforth Journal), Karolinska Krigares Dagböcker (henceforth KKD), XII (Lund 1918): 57-86; M. Stenbock, Kårt Deduction af den Expedition mig uppdragen wart..., Marienburg d:26 Martii 1704 (henceforth Deduction), KKD XII (1918), 87-96; Bref och skrifvelser till Carl XII från Magnus Stenbock 1702-1705, KKD, XII (1918), 123-280 (henceforth Stenbock-Karl XII); Magnus Stenbock och Eva Oxenstierna en brefväxling, utg. av Carl Magnus Stenbock, del I (Stockholm 1913) (henceforth Stenbock- Oxenstierna). I used the letters to Eva Oxenstierna through Łakociński, Magnus; Berättelse om General-Krigskommissariatets viktigaste åtgöranden 1702-1704, (henceforth Berättelse) KKD XII (1918), 281-295.

6 A. Stade, Erik Dahlberg och Carl X Gustafs Krigshistoria (Stockholm 1967), rev. J. Serczyk, Zapiski Historyczne 35 (1970), 2: 119. 
and people's profiles. The author gives many surnames of the Swedes (mainly soldiers) and the Poles, mentions many trivial facts, informs about the movements of the Swedish army in detail, provides its itinerary, describes armed clashes, lists the army units engaged in battle with the numbers of soldiers, informs about the paid tributes and about punishing the reluctant payers. In some cases the names of towns, villages and rivers are deformed, as he might have heard them and not seen their written forms. His attachment to the king is well visible, and so is a strong belief in the rightness of his conduct and in the Swedish raison d'état.

It is worth asking the question what it was that shaped the opinions of the Swedish commanders and determined their attitudes and conduct in Poland. The mentality of the Swedish officers were undoubtedly formed by the political, cultural, moral and religious differences between the Polish Commonwealth and Sweden, and the easy victories over the Polish. The Swedes had the characteristics which were missing in the Polish: the determination to achieve goals, the resilience to hardship, an excellent sense of organisation, of which the army was an example. The victorious army shaped the mentality. The conduct of the Swedish officers was also influenced by their material situation. Poland compared to Sweden was a rich country. The officers of the Carolingian army were not rich landowners as their fathers, but low-paid functionaries of the Crown, who had to desperately struggle to support themselves. Many of them strove to recover the former wealth and importance. War was a means to achieve that aim. The correspondence with his wife, Eva Oxenstierna, a daughter of an ancient influential family, shows the needs and interests of Swedish officers in Poland. In the case of Stenbock, in addition to promotions, war was supposed to pay for everything, from the purchase of a landed estate and a real property in town to their furnishings. It is clearly visible in his letter to his wife written in Estonia in 1701: 'If I could afford to live without serving in the army, I would not serve any longer, even a single day'? In Stenbock's case there was an additional motive: the defence of the real estates, which were still in possession of the family, situated in Livonia. In the letter sent after the battle of Narva he wrote: 'I was given a black eye in defence of her [mother's] Livonian estate', and describing his mother's estate he wrote that 'he saw her estate in Livonia with his eyes full of tears'.

Łakociński, Magnus, 25.

8 M. Kopczyński, "Dania i Szwecja czyli państwa militarne", in: Rzeczpospolita-Europa XVI-XVIII wiek. Próba konfrontacji, eds. M. Kopczyński, W. Tygielski (Warsaw 1999), 117; P. Englund, Poltawa (Gdańsk 2015), 28. 
In spite of the advantages brought by war campaigns, the war itself was arduous. The motif of tiredness of war hardships, of homesickness and of longing for the family and peace frequently appears in Stenbock's letters to his wife. The Saxon diplomacy strove for peace negotiations to finish the war and in December 1700 Stenbock could write to his wife from Narva that he expected that peace would be achieved soon, and in August 1701 he wrote from Courland: 'May God give an end to this war, otherwise we shall all die somewhere.' ${ }^{9}$ At the end of 1701 Charles XII together with his army invaded Lithuania, which meant that the war was brought to the territory of the Commonwealth, although formally Poland was not at war with Sweden and from the beginning had been trying to remain neutral. The war was started by Augustus II, Elector of Saxony, without the consent of the Sejm/Seym (Parliament) of the Commonwealth. The politics of the Polish monarch led to an internal split and a civil war; there appeared two opposing camps: supporters of the Wettiner and followers of the Swedish king. The opposition against the Polish king negotiated with Charles XII and surrendered to him, hoping to overthrow Augustus II. The aim of Charles XII was not a war against Poland but the dethronement of Augustus II. At the beginning of 1702 Stenbock informed his wife that 'we are marching towards Lithuania. The war has been declared'. He underlined that the defensive war had changed into the aggressive one, and he predicted that the Polish would not be inactive. ${ }^{10}$

The attitude of Stenbock towards the Polish and Poland was not different from the one of Charles XII or other Swedish commanders and officers, and it undoubtedly resulted from his military experience. The Polish army was not prepared to war, especially when it was compared with the Swedish army, perfectly organised; the tactics used by the Polish command was not impressive: avoiding a decisive battle, and when forced to it preferring defensive clashes, ${ }^{11}$ as a result, the army of Charles XII won easy victories over the Polish. Those circumstances favoured forming rather a low opinion of the Swedes on the Polish, they confirmed the Swedes in their belief that the Polish army was of low military value and reinforced the disrespectful, or even contemptuous, image of the Polish and Poland. In Stenbock that condescending and sarcastic attitude towards the inhabitants of

9 Łakociński, Magnus, 27.

10 Ibidem; I. Eriksson, Karolinen Magnus Stenbock (Stockholm 2007), 97.

11 J. Wimmer, Wojsko Rzeczypospolitej w dobie wojny pótnocnej (Warszawa 1956), 196; idem, "Polskie wojsko i sztuka wojenna w czasie wielkiej wojny północnej", Studia i Materiały do Historii Wojskowości XXI (1978), 359-370. 
the Commonwealth was visible from the very beginning. When in Autumn 1700 the conflict with Augustus II was approaching he reassured his wife that on the part of the Polish there was no threat, because they were just rogues and peasants; and in spring 1702 he wrote from Lithuania that she did not have to worry about him as the Polish were cowards by nature. ${ }^{12}$ The same overtones could be perceived after the clash with the troops of Michał Wiśniowiecki, the Lithuanian field Hetman in Vilnius in April 1702. Stenbock wrote that the attack was repelled but the Polish 'did not want to fight and the pursuit was a failure, too'. ${ }^{13}$ The General's attitude towards the Polish hardened after the Swedish army occupied Warsaw without a fight (May 1702), after the battle of Klissow (July 1702), after the daring capturing of Cracow (August 1702) and Lublin (the beginning of 1703). In September 1703 the Swedish Corps captured Poznań, in October Torun was captured, in December 1703 the Swedish troops occupied Elbląg without any resistance on the part of the inhabitants. Next they soon occupied the whole of Warmia and a significant part of Royal Prussia. Charles XII did not manage to capture Gdańsk, but the city had to pay high tribute and make many concessions. In September 1704 the Swedes captured Lviv without any effort. In 1705 they dominated in the whole of the country.

The battle of Klissow did not bring the Polish army fame. In the culminating moment when the fate was being decided the Polish companies under the command of Hetman Hieronim Lubomirski retreated from the battlefield. The dishonourable behaviour of the Hetman was not the result of his cowardice, as it was interpreted by the Swedes, and Charles XII sneered at the Polish gentry that they had better turn swords into ploughshares. ${ }^{14}$ Lubomirski represented the overwhelming majority of the Polish gentry of the Commonwealth who wanted to remain neutral and did not want to engage in the war with Sweden, and all the less he intended to help Augustus $\mathrm{II}^{15}$ to win a victory. In that way Lubomirski demonstrated his understanding of the national security which was synonymous with the defence of the king. It was not understood by the majority of the Polish gentry, and the Swedes treated it with contempt. Later on when the Saxon army threatened the Swedish troops Charles XII, remembering the retreat of Lubomirski's companies, responded calmly: 'Let them go wherever they want; they will

\footnotetext{
12 Stenbock - Oxenstierna, Parnawa 16.10.1700, no. 202 and Ragowo 1.03.1702, no. 288.

13 Łakociński, Magnus, 30.

14 Biblioteka Czartoryskich (henceforth B. Czart.), ms. 1995, Relacja z obozu, 19.07.1702, p. 117.

15 K. Piwarski, Hieronim Lubomirski, hetman wielki koronny (Cracow 1929), 89-91.
} 
soon retreat again'. ${ }^{16}$ The king still before the battle of Klissow seemed to be in a very good mood and he was sure of the victory in spite of the fact that the condition of his army was rather poor. After the campaign in Livonia and Lithuania the soldiers of Stenbock's corps were tired and hungry, many of them were ill, and when informed that the artillery forces were not strong enough Charles replied that 'soon we'll capture the enemy's cannons and we'll have more of them than we need'. ${ }^{17}$

The victorious battle of Klissow opened the way for the Swedes to Cracow. On August $10^{\text {th }}, 1702$ Wawel was captured by stratagem, without a single shot, and - as it circulated in the Swedish folk tradition - by one man, Charles XII. The Wawel 200-strong crew did not even try to put up any resistance. Stenbock was given an unlimited power over the city; in a letter to his wife he called himself 'the governor, commissioner and even the devil of the city', which well depicts his actions in the Wawel Stronghold..$^{18}$ The General imposed a high tribute and other taxes on the inhabitants, and he confiscated valuables; his search in the Wawel Cathedral for hidden treasures got a lot of publicity. ${ }^{19}$

Gdańsk was much more difficult to capture. The city had sufficiently strong fortifications to effectively defend itself against the Swedes. Stenbock was entrusted with the task of capturing the city. He arrived in Gdańsk at the beginning of 1703 . Having only 4,000 soldiers he had no chance to capture the city by force. The inhabitants rejected Stenbock's demands to pay tribute, to hand over their artillery and to give consent to place the Swedish garrison at the mouth of the Vistula. The attitude of the inhabitants irritated the king and Stenbock. The king in his letter to Stenbock wrote: 'If the inhabitants of Gdańsk do not treat you seriously, they will pay for it sooner or later'. ${ }^{20}$ The negotiations between the General and the inhabitants took a long time, finally Stenbock forced the inhabitants to pay tribute and to give consent to let in Swedish ships with recruits and military supplies. ${ }^{21}$ Stenbock used his stay in Gdańsk for his private matters. He informed

\footnotetext{
16 Z. Anusik, Karol XII (Wrocław 2006), 91.

17 Ibidem, 88

18 Łakociński, Magnus, 33; A. Górny, K. Piwarski, Kraków w czasie drugiego najazdu Szwedów na Polskę 1702-1709 (Cracow 1932), 25-27.

19 G. Majewska, "Obraz szwedzkiego wojska w Rzeczpospolitej okresu wielkiej wojny północnej (1700-1721)", Slavica Lundensia 28 (2017), 100.

20 Anusik, Karol, 111.

21 E. Cieślak, "W wirze wojny północnej”, in: Historia Gdańska, ed. E. Cieślak, vol. III/1: 1665-1793, part 2: Okres wojen i dekoniunktury gospodarczej (1700-1793) (Gdańsk 1993), 485-508.
} 
his wife what the purpose of his stay was: 'to impose tribute, and at the same time to send you a loot stolen in Poland'. ${ }^{22}$ The king sent Stenbock to Gdańsk several times, also to look after the military transports coming from Sweden and the shipment of prisoners of war and loots and recruitment to the dragoon regiment. In the letters from Gdańsk and Elbląg the general complained to Charles XII about the difficulties to conduct recruitment in Gdańsk; he wrote that the Swedes were not popular in town and none of his compatriots could feel safe there. ${ }^{23}$

In July 1704 Stenbock marches with his regiment southwards to Lviv. ${ }^{24} \mathrm{He}$ spoke about his expedition to Lviv unceremoniously: 'we are going to Lviv rather to make money than to fight'. ${ }^{25}$ Preparing the capturing of the town the general in the company of his officers made a reconnaissance of the fortifications. He talked about them in a disdainful way and declared that he and his soldiers could capture the town without any assistance. 'On September $5^{\text {th }}$ [Charles XII, GM] encircled its walls and the day after he captured it very quickly by storm', and the inhabitants were 'slaughtered, everyone who dared to resist', wrote the author of Historya skrócona Karola XII... ${ }^{26}$

Lviv was captured by storm without any bigger losses. It was a success, but as the defenders did not resist strongly Stenbock and Charles XII did not value the victory highly. He wrote to his wife about the event in that way: 'I'm sure you'll learn through normal channels how HM the king with a sword in his hand captured the city of Lviv. I was present there, got away in one piece and I feel fine'. ${ }^{27}$ The march of the Swedish army was marked with burnt villages and towns.

The Polish were considered to be cowards and not to have the will to fight, and the Polish army was thought to be weak; now new accusations appeared: that they were two-faced, wavering, hypocritical and insincere. Magnus Stenbock as the General Director of the War Office of the Commonwealth was responsible for supplying the army and for its logistics. The Swedish army lived at the expense of the occupied country, depriving it of everything they needed by means of the tributes ruthlessly imposed. Still in June 1702 Stenbock, as the governor of Warsaw,

\footnotetext{
22 Łakociński, Magnus, 79.

23 Stenbock - Karl XII, Gdańsk, 14.11.1703, Elbląg 1.01.1704, 216-220.

24 Anusik, Karol, 124.

25 Lakociński, Magnus, 101.

${ }^{26}$ Historyja skrócona Karola XII króla szwedzkiego z francuskiego na polski język przettumaczona (1755), 33. According to Antoni Hyrcyk, the Polish translator, the author, a Frenchman, was to accompany Charles XII in his campaign in Poland.

${ }^{27}$ Łakociński, Magnus, 102.
} 
tried to make a good impression. Being afraid of the reaction of the inhabitants to the tributes he issued an announcement, which guaranteed them security and a payment for food supplies over the set limits, he was also responsible for the discipline among the Swedish soldiers. ${ }^{28}$ After the battle of Klissow he showed a new face. Fulfilling the duties of the director of the General War Office he proved himself to be not only an efficient organiser but also a ruthless plunderer, who unscrupulously exacted tributes in the form of cash and food supplies from the towns occupied by the Swedes and from landed estates; he tolerated rapes, violence and plundering, of which a significant part of profits lined his pocket. In an appeal to the inhabitants of the south-east voivodships the General announced that evading payments would be punishable by 'royal disgrace and destruction of property', and he also announced that the taxes would be enforced by a military warrant of execution, which meant confiscation of property or burning it. ${ }^{29}$ The king himself confirmed him in using such methods. ${ }^{30}$ On the other hand, so as not to put off the supporters of Sweden in the Commonwealth altogether the king was prone to some concessions. Contradictory directives required flexibility on the part of Stenbock and a skill of manoeuvring. In turn, the Poles collaborating with the Swedes wanted the taxes exacted by the Swedish to be possibly the least burdensome. Hence, also the Polish had to be flexible.

Although many Poles took sides with the Swedes and collaborated with the invader, Stenbock was aware of the fact that the gentry's allegiance to the Swedish king was illusory. Therefore, he had not confidence in the Polish, accused them of insincerity, unscrupulousness and disobedience. The General's attitude towards the Polish was well rendered by the words recorded by Baron Nils Reuterholm, a Swedish diplomat, which Magnus was to utter: 'They [the Polish] should be treated as puppies that are being trained: to pat them, to stroke their heads, but at the same time to flog them with a scourge'. ${ }^{31}$ Stenbock himself wrote: 'The whole of Poland hates us, and although they seem to be our friends when we are together, they murder us all as soon as they catch one of us.....32 In October 1702 in a letter to Charles XII he complained about the disobedience of the Polish and

\footnotetext{
28 M. Wagner, Kliszów 1702 (Warsaw 1994), 31.

29 Central Archives of Historical Records (Archiwum Główne Akt Dawnych), Archiwum Radziwiłłów, Jnl. II, no 1970, file 14, Appeal of the General Commissioner (Odezwa Generalnego Komisarza) Gen. Stenbock 23.10.1702.

30 Deduction, 87-88.

31 "Nils Reuterholms Journal", Historiska Handlingar 36 (1957), 2: 15.

32 Łakociński, Magnus, 30; Stenbock - Oxenstierna, vol. I, no. 300, 29.06.1702.
} 
expressed a belief that the only way to force them to be loyal and obedient was to punish them ruthlessly by fire and sword. He complained about the stubbornness of the Polish and the difficulties in exacting the taxes. Magnus accused the gentry of Lesser Poland of insubordination, he wrote 'The local gentry were so stubborn that none of them, who lived tree miles off the road, would not come here, unless I went to their place...' (the point was to bring tribute to the Swedish camp) ${ }^{33}$ In his diary he often described cases of abandoning homesteads and taking away all the property by the owners before the Swedish quartermasters arrived in the village to exact the tribute. He added that such a village used to be burnt down as punishment. ${ }^{34}$ Rural homesteads were burnt also when the owners encouraged the peasants to resist against the Swedes. As Stenbock wrote in his diary, in one of the villages in Lesser Poland the homestead and the presbytery were burnt down because the priest and the starosta (a seneschal, a senior royal administrative official) instigated the peasants to rebellion and then they escaped..$^{35}$ Magnus often complained to the king about the difficulties in exacting tribute. In one of his letters he wrote: '...everybody escaped leaving their homesteads and taking everything they could..., but at the same time he assured that he would do everything he could to collect what was due. ${ }^{36}$

Hypocrisy, unscrupulousness, the gift of persuasion and flexibility were the characteristics, according to Stenbock, of Stefan and Józef (especially Józef), Great Crown Hetman Feliks Potocki's sons. On the one hand, they seemed to be supporters of the Swedes who declared loyalty to Charles XII; on the other hand, they were leaders of the gentry's resistance against paying tribute. ${ }^{37}$ Thus, Potocki could be compared to Stenbock in his unscrupulousness and flexibility, he might have even exceeded the general. Angry with the behaviour of Józef the general complained to the king that Potocki, like all the Polish, was crafty and beguiled them; embittered Magnus claimed that: '...there is even not a single honest Pole in the whole of Poland, unless he has his own interest in mind'. ${ }^{38}$

The ruthless methods of exacting taxes were also used by other Swedish commanders. Plundering of towns and villages and burning them down were frequent.

\footnotetext{
Stenbock - Karl XII, Pilzno 29.10.1702, p. 136; Łakociński, Magnus, 48, 49.

34 Journal, 63; Stenbock - Karl XII, Dębica 31.10.1702, p. 137.

35 Journal, 63.

36 Stenbock - Karl XII, Sokal 23.01.1703, p. 154.

37 Deduktion, p. 93.

38 Stenbock - Karl XII, Sokal 23.01.1703, p. 153; cf:: Łakociński, Magnus, 67.
} 
It triggered in the Poles stronger and stronger negative reactions. The tactics commonly used was the one of scorched earth, the property was hidden, the inhabitants took shelter in inaccessible places, or even took up arms against the invader. Stenbock reluctantly had to agree with Potocki that common sense required the terror to be reduced, but ' ....in the meantime, I am prowling like a devil, and I grab whatever I can..., he wrote. ${ }^{39}$

Stenbock was also charged with the task of convincing the obstructive voivodships to support Charles XII. The general kept sending numerous appeals to the gentry demanding that fighting be stopped and Augustus II dethroned. Negotiations with the gentry hardly brought anything, the Swedish arguments were not convincing, which - according to Stenbock - was a result of Polish stubbornness. 'The worst thing is the Polish are so stubborn as mules, and they will do only what they want themselves', he claimed. ${ }^{40}$ When the attempts to convince the Polish turned out to be fruitless, Magnus tried other means - blackmail, violence, plundering - to get support on the part of the gentry. It was well illustrated by the case of Jan Stadnicki, the voivode of Volhynia (Polish: Wołyń). The Swedish commander informed the king that he was going to detain the voivode until the gentry declared support for the Swedes, otherwise Potocki would be shot dead. ${ }^{41}$ Stenbock attitude towards Hieronim Lubomirski was friendlier. 'The landed estates of the Hetman will be burnt down unless he goes over together with his troops to Charles XII's side', announced Magnus. There were more cases of that type. Rzeszów was threatened to be ravaged and burnt down if the Crown army with General Brant did not join the Swedish. ${ }^{42}$ Stenbock with deliberation kept destroying estates belonging to the supporters of the Saxon; he also destroyed the properties belonging to people who were not loyal to Charles XII.

The Swedish commander did not have any confidence in Hetman Hieronim Lubomirski in spite of his assurances of loyalty. In Autumn 1702 in a letter to the king Magnus wrote: 'The Hetman [Lubomirski] renders me all the possible honours, he announces that he wants to pay tribute regularly, that he has given his troops orders not to take up arms against the Swedish; but, as I don't believe his assurances I have given the order to arrest everything which will seem suspicious

\footnotetext{
39 Łakociński, Magnus, 68.

40 Stenbock - Karl XII, Dąbrowa 25.10.1702, p. 133.

41 Stenbock - Karl XII, Rzeszów 24.12.1702, p. 145; cf:: Berättelse, 285.

42 B. Czart, ms 196, Doniesienie wiadomości podczas szwedzkiej inkursji, 13 XI 1702, p. 1194; B. Czart, ms, 525, Relacja posłańca hetmana Lubomirskiego z rozmowy ze Stenbockiem z 5.01.1703, p. 253.
} 
to me'. ${ }^{43}$ Lubomirski's attitude towards the Swedish was wavering; he manoeuvred between the support to Augustus and the support to Charles. He wanted to keep neutrality between the fighting parties; as a result he won nobody over and put many off. Among the Swedes he had an opinion of a man who was capable of concessions but who did not deserve confidence. Stenbock had no confidence in Lubomirski, but he did not keep his own promises given to Lubomirski. He guaranteed the Lubomirski's envoy the security of his estates, but he broke his promise. He exacted high tribute from Lubomirski's properties in the Rzeszów Region without leniency. ${ }^{44}$ Inability to compromise and quarrelsomeness had a negative impact on the regime of the Commonwealth according to Stenbock. The gentry could not reach an agreement at Sejmiki (the regional-level elected legislature); the Sejmik of the Belz Voivodeship, which debated for four days, ended in a fiasco, as the general wrote..$^{45}$

Other defects of the Polish mentioned by Stenbock were envy and vindictiveness. According to him, they helped the Swedes find hidden property and exact tribute. As a result of denunciation, from the very beginning of the occupation of Cracow, as soon as the Swedish soldiers had been accommodated, they started looking for real or alleged deposits left by the inhabitants who had left the town fleeing from the war. ${ }^{46}$ Moving in the Polish aristocratic circles Stenbock noticed intrigues and dissolution. He observed sexual relations among the Polish aristocracy kept changing. He had a low opinion of women of the Commonwealth. In a letter to his wife he wrote that women in Poland were like 'medusas, and a cure for love' ${ }^{47}$ Undoubtedly, such an opinion is an expression of hypocrisy of the author, and probably it was due to calm his wife; Magnus was difficult to please as far as women were concerned, among the Swedish elites he had a reputation of being a dissolute womanizer.

Stenbock did not like the Polish, but in official relations with the Polish community he displayed some positive feelings. After a feast organised by Rzeszów Piarists to celebrate the Swedish commander, the general invited the monks to another feast in the castle. There were toasts, and the Swede gave the Piarists

\footnotetext{
43 Stenbock - Karl XII, Dębica 31.10.1702, p. 137, quote after Łakociński, Magnus, 50.

44 B. Czart, ms 525, Relacja posłańca hetmana Lubomirskiego z rozmowy ze Stenbockiem z 5.01.1703, p. 253; Berättelse, p. 284.

45 Stenbock - Karl XII, Bełz 20.01.1703, p. 149.

46 Górny, Piwarski, Kraków, 31; Łakociński, Magnus, 41.

47 Łakociński, Magnus, 120.
} 
a painting of St Stanislaus Kostka, and allowed them to look for food in less destroyed areas. In Warsaw, where there were negotiations on the tribute, the occupational authorities and the Swedish soldiers displayed a positive attitude towards the local authorities and inhabitants, but after signing the agreement the Swedish party intensified their restrictive activities. After capturing Torun the winners behaved in a polite way at the beginning, the Saxon commanders and officers were entertained to dinner, and the soldiers were given provisions; but those friendly gestures were followed by a heavy Swedish occupation. ${ }^{48}$

While staying in Poland Stenbock often complained about the hardship of the marches of his troops and other military actions, and especially about the army supply. Swedish army commanders complained about the bad condition of the roads, especially in the south-east regions of Poland. 'Our horses might suffer because of bad road', wrote Stenbock from somewhere around Rzeszów. ${ }^{49}$ Since the beginning of 1703 the Swedish army was plagued with food shortage. Exacting tribute was more and more difficult in the country enfeebled by war. In February 1705 the general sent from Braniewo a message to the king that the country was burnt and ravaged, and peasants suffered from hunger. He wrote that he did not neglect anything, that he used all the possible means, strict discipline and severity so as to exact the highest possible taxes. The troops that exacted taxes were sent everywhere. Yet, Magnus noticed that it was impossible to act too unceremoniously, as everybody would flee to Brandenburg, leaving empty walls. ${ }^{50}$ In July of the same year, he complained that the tribute from Warmia had been only partly collected, because the impoverished gentry could not pay anything from their burnt estates. ${ }^{51}$ Stenbock was worried by the threat on the part of Polish and Saxon troops to disrupt the transport links. He felt acute anxiety about the collected treasure and how to safely send it to Sweden, especially when the army was far away from the safe seaside bases. At the end of 1704 from Wschowa he wrote to his wife: '... as soon as my luggage arrives, I'll send you, Angel, my loot, unless it is stolen somewhere en route. ${ }^{52}$

\footnotetext{
48 J. Nieć, Rzeszowskie za Sasów: szkic historyczny (Rzeszów 1938), 45; M. Wagner, Kliszów 1702 (Warsaw 1994), 37; J. Poraziński, "Oblężenie Torunia w 1703 r.: uwagi i refleksje w związku z 300 rocznicą", Rocznik Toruński, 30 (2003): 75.

49 Stenbock - Karl XII, Strzyżów 4.12.1702, p. 140.

50 Stenbock - Karl XII, Braniewo 23.02.1705, p. 263.

51 Stenbock - Karl XII, Malbork 15-25.07.1705, p. 271.

${ }^{52}$ Łakociński, Magnus, 104, 106
} 
More optimistic news appeared much less frequently in the reports and correspondence of the Swedish general. Here are some examples: in March 1702 from Wiłkomierz, Lithuania he wrote to his wife: 'It is OK here. We're sleeping, eating and drinking free of charge, end even sometimes we are given money, and we shall as long as we can...'; in October of the same year from Cracow: 'Thank God I feel fine and live like a grand seigneur, I eat using silverware and I have my own six musicians'. ${ }^{53}$ The lavish life of the Polish aristocracy and gentry was undoubtedly attractive for the people who were not accustomed to luxury and splendour. Higher officers from the circles around Charles XII would have very fond memories of their stay in Poland (June 1702). A rich social life flourished there, with marvellous feasts and balls. And Stenbock was known for his penchant for grand feasts and parties, he became famous for organising fetes and various celebrations. A good example could be the ceremonies at the Castle in Rzeszów (November 1702) to celebrate the victory over Hieronim Lubomirski, which was immortalised in print. ${ }^{54}$

The long-lasting occupation of the Commonwealth undoubtedly had an impact on the Swedish invaders. As a result of the contacts with the local population, which not always were hostile, the Swedes gained a lot. Stenbock, a sociable person, established contact with Polish supporters of the Swedish and Stanisław Leszczyński. The Swedes were interested in colourful exotic attire of the Polish. The general was leaving Cracow in 1702 dressed in a Hungarian robe with a Polish sabre. ${ }^{55} \mathrm{He}$ must have liked pickled cucumbers because he wrote to his wife: 'I'll do everything I can to deliver the recipe for pickling cucumbers'. ${ }^{56}$

Stenbock criticised the battle worthiness of the Polish army, but in a critical moment for Sweden he introduced Polish solutions. Preparing the defence of Scania against the Danish invasion at the beginning of 1710, he used the Polish models and demanded levy in mass of peasants be organised following the example of Poland. So as to keep order a few officers were assigned to the peasants and the commander-in-chief was appointed in the rank of general. That solution fully worked very well in battlefield. ${ }^{57}$

\footnotetext{
53 Ibidem, 29, 35

54 Nieć, Rzeszowskie, 44.

55 Górny, Piwarski, Kraków, 43.

56 Łakociński, Magnus, 97.

57 Ibidem, 122.
} 
The war was an occasion for capturing spoils. Plundering took place openly, with the king's knowledge and consent, as well as the transports of the war spoils to Sweden. Stenbock's participation in the war spoils was probably bigger than other officers of the Swedish army, which resulted from the position he occupied in the court of Charles XII, from his official posts, especially the post of director of the General War Office, from the key role that he played in the most important battles, and also from the post of the governor of Warsaw, Cracow and Torun'; as the governor he was given gifts in cash and in kind. Capturing the spoils of war did not cost him much effort or attention. In the correspondence with his wife the artefacts he stole in Poland and their safe transport to Sweden took a lot of room. In Autumn 1701 he sent from Courland a red coat trimmed with a gold tape lined with fur. ${ }^{58}$ With the distance to the Baltic ports growing longer, the communication with Sweden became more difficult, and in a letter from Kavarskas, Lithuania Magnus complained that he could not send linen, which was there the most beautiful in the world and cheap; from Vilnius he wrote: 'I have multiplied my property here in Lithuania with silver bowls and spoons, with horses and robes'; in Lithuania he also collected church silverware and chasubles. ${ }^{59}$ In 1704 from Rawicz he sent 'two tablecloths and two dozen doilies, there aren't prettier'; from Toruń he wrote: 'I captured a pretty, however small, loot in Torun, which I'll sent to you. It is not valuable, but still it is a nice souvenir from Poland ${ }^{\prime} \cdot{ }^{60}$ For Stenbock and other Swedes the most valuable acquisitions were: Polish weaponry, silverware, richly ornamented attire, horse tack, tapestries, valuable fabrics, bedclothes. During his stay in Greater Poland the general wrote to Eva Oxenstierna: 'We are here in the land of beautiful bedclothes'. He sent to Sweden also tablecloths, tableware, tents, carpets, mirrors, candlesticks, furs, clocks, paintings ${ }^{61}$

Staying for five years in the Commonwealth Magnus Stenbock had many occasions to get to know the Polish. Many features of the Polish character undoubtedly deserved to be condemned. Yet, quite often his opinions were exaggerated, simplified or unjust. Stenbock, like other Swedish commanders, seemed not to notice that maintaining a foreign army in a country being destroyed by both parties (the Polish were harassing the enemy) had to trigger a reaction. He seemed not to understand that the situation in which the collaborating Polish were required

\footnotetext{
58 Stenbock-Oxenstierna, a letter dated 10.10.1701, p. 159.

59 Deduction, 95.

60 Lakociński, Magnus, 29, 91, 107.

61 Ibidem, 122-123.
} 
a lot of flexibility and the skill of manoeuvring, so that the tributes and other taxes exacted by the invader would be possibly the lowest. He did not want to accept the fact that the fickleness and hypocrisy of the Polish society, which the Swedes complained of, resulted from the hostile conduct of the foreign army contrary to their declared friendly attitudes. He seemed not to understand that violence and plundering of the Swedish army were the reason the followers of Charles backed down from their pledge to support him.

Assessments and opinions given by Magnus Stenbock on Poland and their inhabitants did not differ from the ones given by Charles XII and other Swedish commanders participating in the Great Northern War. ${ }^{62}$ The Polish were accused of recklessness, duplicity, instability, unscrupulousness, unruliness, self-interest. The gentry were criticised for betraying their obligations, for conceit and a condescending attitude towards the others. The battle worthiness of the Polish troops was ridiculed, they were accused of indiscipline and disobedience. On the other hand, the weaponry and soldiers' kit of the Polish winged Hussars were impressive. The regime of the Commonwealth was criticised. The Swedes were shocked at the unlimited freedom of the gentry, which crippled the Parliament and the Sejmiki; it surprised them that the king was not respected.

\section{Bibliography}

\section{Sources}

Central Archives of Historical Records (Archiwum Główne Akt Dawnych), Archiwum Radziwiłłów, Jnl. II, no. 1970, file 14, Appeal of the General Commissioner (Odezwa Generalnego Komisarza) Gen. Stenbock 23.10.1702.

Berättelse om General-Krigskommissariatets viktigaste åtgöranden 1702-1704, Karolinska Krigares Dagböcker, vol. XII, Lund 1918.

Bref och skrifvelser till Carl XII från Magnus Stenbock 1702-1705, Karolinska Krigares

Dagböcker, vol. XII, Lund 1918.

Biblioteka Czartoryskich, ms 196, 525, 1995,

Journal över expeditionen 1702-1703 af generalmajoren, grefve Magnus Stenbock, Karolinska Krigares Dagböcker, vol. XII, Lund 1918.

${ }^{62}$ Cf.: G. Majewska, "Szwedzkie elity w XVII i XVIII wieku o Polsce i jej mieszkańcach", Slavica Lundensia 26 (2011): 39-60. 
M. Stenbock, Kårt Deduction af den Expedition mig uppdragen wart..., Marienburg d:26 Martii 1704, Karolinska Krigares Dagböcker, vol. XII, Lund 1918.

Magnus Stenbock och Eva Oxenstierna en brefväxling, utg. av Carl Magnus Stenbock, del I, Stockholm 1913.

“Nils Reuterholms Journal”, Historiska Handlingar 36 (1957), 2.

Anusik Z. Karol XII. Wrocław, 2006.

Asker B. "Officerarna och det svenska samhället 1650-1700”, Studie Historica Uppsaliensie 133 (1983).

Cavallie J. "De höga officerarna. Studier i den svenska militäre hierarkien under 1600 talets senare del", Militärhistoriska studier 4 (1981).

Cieślak E., “W wirze wojny północnej”. In: Historia Gdańska, ed. E. Cieślak. Vol. III/1: 1665-1793, part 2: Okres wojen i dekoniunktury gospodarczej (1700-1793). Gdańsk, 1993.

Englund P. Poltawa, Gdańsk 2015.

Eriksson I. Karolinen Magnus Stenbock. Atlantis, 2007.

Górny A., Piwarski K. Kraków w czasie drugiego najazdu Szwedów na Polskę 17021709. Cracow 1932.

Kopczyński M. "Szlachta i państwo w XVI-XVIII wieku - model szwedzki”, Przegląd Historyczny 3 (1996).

Kopczyński M. “Dania i Szwecja czyli państwa militarne”. In: Rzeczpospolita-Europa XVI-XVIII wiek. Próba konfrontacji, eds. M. Kopczyński, W. Tygielski. Warsaw, 1999.

Łakociński Z. Magnus Stenbock w Polsce. Przyczynek do historii szwedzkich zdobyczy w czasie wojny północnej. Wrocław, 1967.

Majewska G. "Obraz szwedzkiego wojska w Rzeczpospolitej okresu wielkiej wojny północnej (1700-1721)”, Slavica Lundensia 28 (2017).

Majewska G. "Szwedzkie elity w XVII i XVIII wieku o Polsce i jej mieszkańcach", Slavica Lundensia 26 (2011).

Marklund A. "Magnus Stenbock: the Count and the Spy", History Today 60 (2010) October.

Marklund A. Stenbock. Ära och ensamhet i Karl XII:s tid (Historiska Media: 2008).

Nieć J. Rzeszowskie za Sasów: szkic historyczny. Rzeszów, 1938.

Piwarski K. Hieronim Lubomirski, hetman wielki koronny. Cracow, 1929.

Poraziński J. "Oblężenie Torunia w 1703 r.: uwagi i refleksje w związku z 300 rocznicą", Rocznik Toruński 30 (2003). 
Stade A. Erik Dahlberg och Carl X Gustafs Krigshistoria (Stockholm 1967), rev. J. Serczyk, Zapiski Historyczne 35 (1970), 2.

Wagner M. Kliszów 1702. Warsaw, 1994.

Wimmer J. "Polskie wojsko i sztuka wojenna w czasie wielkiej wojny północnej”, Studia i Materiały do Historii Wojskowości XXI (1978).

Wimmer J. Wojsko Rzeczypospolitej w dobie wojny pótnocnej. Warsaw, 1956.

\title{
RZECZPOSPOLITA I JEJ MIESZKAŃCY W DOBIE WIELKIEJ WOJNY PÓŁNOCNEJ W OPINII GENERAŁA MAGNUSA STENBOCKA
}

Slowa kluczowe: Polska, Szwecja, wojna północna, Magnus Stenbock

\begin{abstract}
Abstrakt
Magnus Stenbock należał do najwybitniejszych dowódców w armii Karola XII czasu wielkiej wojny północnej (1700-1721). Na ziemiach polskich przebywał w charakterze okupanta wraz ze szwedzkim wojskiem w latach 1702-1706. Jego nastawienie do Polski i Polaków wynikało z doświadczeń wojennych, zwłaszcza łatwych zwycięstw odnoszonych nad Polakami. Zwycięstwa utwierdziły Szwedów w przekonaniu o małej wartości militarnej armii przeciwnika i sprzyjały utrwaleniu się lekceważącego, przechodzącego w pogardę stosunku do mieszkańców ziem Rzeczpospolitej. Mimo że wielu Polaków stanęło po szwedzkiej stronie i współpracowało z najeźdźcą, Stenbock nie darzył ich zaufaniem, zarzucał obłudę, dwulicowość, niestałość w poglądach, oskarżał o nieposłuszeństwo i brak skrupułów. Sytuacja w jakiej znaleźli się kolaborujący z Karolem XII Polacy wymagała umiejętności lawirowania, tak by ściągane kontrybucje były możliwie najmniej uciążliwe. Bezwzględne metody ściągania przez Szwedów kontrybucji wyzwalały jednak w Polakach nieposłuszeństwo i opór. Obracając się wśród polskiej arystokracji i szlachty, Stenbock dostrzegał skłócenie, intrygi, rozwiązłość. Atrakcyjny dla szwedzkiego generała, nieprzywykłego do zbytku i przepychu, był wystawny tryb życia polskich wyższych sfer. Zainteresowanie budził nie tylko egzotyczny ubiór Polaków, ale także broń, srebrne zastawy stołowe, dywany, kosztowne tkaniny, futra, pościel, obrusy, lustra, zegary, obrazy. Wiele z tych przedmiotów Stenbock wywiózł w postaci łupów do Szwecji. Generał krytycznie oceniał wartość bojową polskiej armii, ale dla obrony Skanii przed Danią utworzył pospolite ruszenie chłopów na wzór polski. Przebywając 5 lat na ziemiach polskich Magnus Stenbock miał wiele okazji dobrze poznać Polaków. Często jednak wydawał uproszczone, przesadzone i niesprawiedliwe oceny. Wiele cech polskiego charakteru zasługiwało niewątpliwie na potępienie, ale na chwiejność,
\end{abstract}


dwulicowość, lawirowanie czy nieposłuszeństwo społeczeństwa polskiego, na co skarżył się generał, wpływała sytuacja w jakiej znaleźli się kolaborujący ze Szwedami Polacy oraz postępowanie obcego wojska. Oceny i sądy wydawane przez Magnusa Stenbocka na temat Polski i jej mieszkańców nie odbiegały od opinii formułowanych przez Karola XII oraz innych szwedzkich dowódców wojskowych. 